\title{
Małgorzata Rószkiewicz
}

Szkoła Główna Handlowa w Warszawie

e-mail: mroszki@sgh.waw.pl

\section{OCENA WPLYWU TEMATYKI BADANIA ORAZ ORGANIZACJI PROCESU BADAWCZEGO NA POZIOM WSKAŹNIKA BRAKU ODPOWIEDZI - PORÓWNANIE PODEJŚĆ ANALITYCZNYCH}

\section{ASSESSING THE IMPACT OF RESEARCH TOPICS AND RESEARCH PROCESS ORGANIZATION ON THE LEVEL OF NONRESPONSE RATE - COMPARISON OF ANALYTICAL APPROACH}

DOI: 10.15611/ekt.2017.4.01

JEL Classification: C80, C83.

Streszczenie: W artykule zbadano możliwości analityczne i walory poznawcze w oszacowaniu wielkości efektu wpływu organizacji procesu badawczego na poziom wskaźnika braku odpowiedzi na podstawie historii kontaktów w badaniu polskich gospodarstw domowych. Odrębnie przeanalizowano uwarunkowania braku kontaktu oraz odmowy odpowiedzi. W ramach różnych rozwiązań analitycznych dokonano oceny wielkości efektu netto za pomocą prostego porównania podzbiorowości uczestniczących i odmawiających lub niedostępnych, a także wykorzystano technikę dopasowania próby według cech, posługując się modelem regresji logistycznej oraz modelem hybrydowym w szacowaniu indeksu skłonności oraz transformacją przestrzeni wielowymiarowej w skalar według wielowymiarowej analizy korespondencji. Najlepsze dopasowanie porównywanych grup osiągnięto według modelu logitowego oraz według wielowymiarowej analizy korespondencji.

Słowa kluczowe: wskaźnik braku odpowiedzi, błąd braku realizacji, efekt procesu badawczego.

Summary: The article presents an attempt to identify the causal effect of the research process on the level of the response-rate in the study of Polish households conducted in 2013. Conditions for lack of contact and refusal were analyzed separately. The net causal effect was assessed by simply comparing the subsets of the participating and refusing units or unavailable units and matched paired units. In matched paired approach for estimating propensity index the technique of the logistic regression model, the hybrid model and multidimensional correspondence analysis ware used. Socio-economic status of the units was taken as the independent variable. The best match for the compared groups was achieved by logit model and multivariate analysis of correspondence.

Keywords: nonresponse-rate, noncooperation-rate, effect of research process. 


\section{Wstęp}

Podstawowymi źródłami niskiego poziomu wskaźnika odpowiedzi w badaniach terenowych jest błąd wyboru oraz błąd braku reakcji. Błąd wyboru związany jest z zaniechaniem lub niemożnością nawiązania kontaktu z respondentem, błąd braku reakcji zaś dotyczy odmowy udziału w badaniu. Dostępność respondenta oraz gotowość podjęcia przez niego współpracy stanowią dwa odrębne wymiary realizacji próby [Stinchcombe, Jones, Sheatsley 1981; Goyder 1987; Groves, Couper 1998; Lynn 2002]. Ich rozróżnienie jest ważne $\mathrm{z}$ wielu powodów, z których istotne w największym stopniu wydają się dwa. Po pierwsze, planując badanie, należy wypracować strategie gwarantujące oczekiwaną precyzję dla kluczowych wyników, a która związana jest w pierwszej kolejności z osiągnięciem wymaganego wskaźnika odpowiedzi. Zagrożenie osiągnięcia wymaganego poziomu dla tego wskaźnika wymaga podjęcia działań zapobiegawczych, które są inne w przypadku trudności w nawiązaniu kontaktu, a inne w przypadku odmowy udziału w badaniu. Po drugie zaś, w analizach porównawczych wyników serii badań konieczne jest posiadanie wiedzy, czy procesy badawcze były porównywalne. Identyczne lub zbliżone wartości wskaźnika odpowiedzi mogą kryć znaczne różnice dotyczące trudności w nawiązaniu kontaktu oraz występowania odmowy udziału w porównywanych badaniach, co sytuuje porównywane badania w odmiennych uwarunkowaniach.

Dane dotyczące zaangażowania respondentów w Polsce w proces realizowanego badania są rzadko, jeśli w ogóle, publikowane. Na ogół badacze ograniczają się do podania wskaźnika odpowiedzi, nie charakteryzując uwarunkowań jego poziomu. $\mathrm{W}$ toku prowadzonych analiz historii kontaktów badania ankietowego zrealizowanego w 2013 r. na losowej próbie 33631 gospodarstw domowych, w ramach projektu $\mathrm{UDE}^{1}$, rozpoznano czynniki istotnie wpływające na kształtowanie się wskaźnika odpowiedzi w środowisku gospodarstw domowych w Polsce [Rószkiewicz 2015; 2016]. Wśród czynników tych wyróżniono zarówno cechy społeczno-ekonomiczne gospodarstw domowych, jak i cechy samego procesu badawczego. Wyniki te wskazały, że brak kontaktu oraz odmowy odpowiedzi są odmiennie uwarunkowane. Zrealizowane do tej pory prace nie określiły jednak, jaki jest efekt wpływu tych czynników w kształtowaniu wskaźnika odpowiedzi. Obecnie podjęto próbę oceny tego efektu w zakresie tematyki badania oraz cech procesu badawczego. W ramach tej próby oceniono własności różnych rozwiązań analitycznych.

\footnotetext{
${ }^{1}$ Badanie było prowadzone w ramach projektu systemowego pod nazwą „Badanie jakości i efektywności edukacji oraz instytucjonalizacja zaplecza badawczego" współfinansowanego ze środków Europejskiego Funduszu Społecznego w ramach Programu Operacyjnego Kapitał Ludzki. Projekt koordynowany był przez Instytut Badań Edukacyjnych, a jego metodologię zaproponował zespół badaczy ze Szkoły Głównej Handlowej w Warszawie. Pełne informacje o projekcie są ulokowane na stronie: http:// eduentuzjasci.pl/ude.
} 


\section{Problemy organizacyjne badań przyczynowych}

Ocena efektu wpływu wybranych czynników na poziom zjawiska wiąże się z badaniami przyczynowymi. W rozpoznaniu zależności między zmiennymi $\mathrm{w}$ nauce występują dwa podstawowe typy badań, tj. obserwacja i eksperyment. W ramach obserwacji są rejestrowane poziomy lub kategorie badanych zmiennych i w tym sensie jest to badanie opisowe, bez ingerencji badacza. Z kolei istota badań eksperymentalnych sprowadza się do oceny związku przyczynowo-skutkowego między testowanymi (kontrolowanymi) czynnikami i zmienną zależną na podstawie świadomie dokonanej manipulacji tymi czynnikami oraz przy braku innej hipotezy wyjaśniającej występowanie związku lub jego brak [Aakar, Day 1990, s. 313-315].

Czynnik kontrolowany to zmienna traktowana przez badacza jako potencjalna przyczyna systematycznej zmienności zmiennej zależnej. Jest on zmienną manipulowaną, gdyż jej wartości lub kategorie są kontrolowane w trakcie eksperymentu.

Obok testowanych czynników w badaniach przyczynowych wyróżnia się również tzw. czynniki zakłócające. Są to zmienne, które obok czynników kontrolowanych mogą również powodować systematyczną zmienność zmiennej zależnej, a których wpływ nie jest przedmiotem badania. Należy dążyć do takiej organizacji eksperymentu, by wpływ tych czynników wyeliminować lub przynajmniej kontrolować. Kontrola czynników zakłócających ma na celu odróżnienie wpływu działania eksperymentalnego od wpływu czynników ubocznych. Bez spełnienia tego warunku nie można mówić o trafności wewnętrznej eksperymentu. Jest to możliwe tylko wówczas, gdy grupy objęte badaniem i wyróżnione przez nadanie im poszczególnych wariantów zmiennych kontrolowanych są, statystycznie rzecz biorąc, homogenicz$n^{2}$ względem wszystkich innych zmiennych, czyli inaczej mówiąc - różnią się tylko czynnikami kontrolowanymi. Wówczas zagwarantowana jest ich porównywalność i określa się je mianem ekwiwalentnych. Charakter losowy czynnikom ubocznym gwarantuje spełnienie zasady randomizacji w organizacji porównywanych grup. Kontrola ta może być również realizowana przez starania o eliminację czynników ubocznych lub równomierne rozdzielenie ich oddziaływania na wszystkie grupy porównywane poprzez ustalenie stałej wartości lub stałego podzakresu zmiennej lub zmiennych zakłócających w podgrupach objętych badaniem, wyrównanie badanych grup pod względem charakterystyk opisowych zmiennej zależnej przed realizacją eksperymentu, zastosowanie doboru wiązanego matched samples lub poprzez monitorowanie wpływu zmiennych zakłócających.

W wielu przypadkach jednak względy praktyczne lub etyczne zmuszają badaczy do prowadzenia jedynie obserwacji w miejsce badania eksperymentalnego. Specyfika eksperymentu naukowego wiąże się bowiem, po pierwsze, ze skalą badania, która na ogół jest mała, po drugie zaś - z kreowaniem sytuacji i ujawnianiem reakcji, które

${ }^{2}$ Tzn. nie występuje systematyczna zmienność grup objętych badaniem względem innych zmiennych niż czynniki kontrolowane, obserwowane zaś zróżnicowanie ma jedynie charakter losowy. 
w normalnych warunkach nie musiałyby się ujawnić, ale są wyobrażalne lub przewidywane. Kreowanie kontrfaktycznych sytuacji nie jest jednak w wielu domenach badań możliwe.

W obserwacji czynnik kontrolowany jest zmienną klasyfikacyjną, gdyż jej wartości lub kategorie są przynależne jednostkom niejako ex ante i stanowią ich cechy charakterystyczne. Nie mogą być przedmiotem manipulacji $\mathrm{w}$ realizowanym badaniu. W przypadku oceny wpływu zmiennych klasyfikacyjnych często mówi się o quasi-eksperymencie lub o modelach ex post facto, gdyż dotyczy ona takich sytuacji, w których obserwowana jest jedynie zmienna zależna i szuka się potencjalnych przyczyn jej zmienności, które zadziałały niezależnie od woli badacza i poza jego kontrolą. Ale wykorzystując jedynie wyniki obserwacji do oceny związku przyczynowo-skutkowego, badacz nie ma kontroli nad doborem jednostek do grup, które podlegają porównaniu (grupa eksperymentalna i kontrolna). W miejsce homogeniczności porównywanych grup pod względem tzw. zmiennych zakłócających występuje ich heterogeniczność. Nie można zatem stwierdzić, czy poziom zmiennej zależnej jest efektem działania czynników kontrolowanych czy też zmiennych zakłócających. Porównanie bezpośrednie obu grup nie daje zatem podstaw do wnioskowania o związkach przyczynowo-skutkowych. Stąd dysponując jedynie wynikami obserwacji, sięga się do metod, które pozwalają osiągnąć homogeniczność porównywanych grup pod względem zmiennych zakłócających ex post facto, zwanych również schematami prób dopasowanych według cech. Do procedur tych należy technika Propensity Score Matching (PSM).

\section{Dopasowanie według cech}

Istota technik dopasowania według cech sprowadza się do wyrównania porównywanych grup pod względem tych wszystkich zmiennych, które są osiągalne w toku obserwacji, a które uznaje się za zakłócające. W zakresie tych właśnie cech dąży się do osiągnięcia ekwiwalentności porównywanych grup, co określa się w technice PSM mianem zbalansowania zmiennych [Rosenbaum, Rubin 1983]. Zbalansowanie to osiąga się poprzez dopasowanie na podstawie wartości tylko jednej zmiennej $(Y)$, którą konstruuje się jako funkcję zmiennych uznanych za zakłócające $\left(X_{j}\right)$ :

$$
Y_{i}=f\left(X_{1}, X_{2}, \ldots, X_{k}\right)+\xi .
$$

Przyjmuje się zatem, że o przynależności do grupy eksperymentalnej decyduje nieobserwowalna zmienna $Y$, a obserwowane są jedynie stany odnoszące się do przynależności do grupy eksperymentalnej $(i=1)$ lub kontrolnej $(i=0)$. Stany te są zatem opisywane przez zamienne dyskretne, czyli [Gruszczyński 2002, s. 11-50]:

$$
z=\left\{\begin{array}{l}
1 \text { dla } Y \geq y^{*} \\
0 \text { dla } Y<y^{*}
\end{array} .\right.
$$


Modele tego typu zmiennych noszą nazwę modeli zmiennych dyskretnych [Maddala 2001, s. 317-338]. Propozycja Rosenbauma i Rubina, określana mianem PSM, jest podejściem parametrycznym, w którym modele nieliniowe są szacowane metodą największej wiarygodności i wymagane jest spełnienie restrykcyjnych założeń o składniku losowym. W modelu regresji logitowej i probitowej wymagane jest, by składnik losowy był homoskedastyczny, w modelach tobitowym i regresji uciętej zaś dodatkowo wymaga się normalności jego rozkładu. Obligatoryjna jest też niezależność zmiennych objaśniających.

Dla modeli zmiennych dyskretnych proponuje się również algorytmy modelujące przynależność do wyróżnionych stanów według podejścia semiparametrycznego i nieparametrycznego. W podejściu semiparametrycznym dokonuje się poluzowania założeń dotyczących składnika losowego modelu regresji zmiennej objaśnianej względem zmiennych objaśniających, co upraszcza procedury estymacyjne i poprawia własności uzyskiwanych estymatorów szacowanych parametrów równania regresji. Utrzymywane jest założenie o postaci funkcyjnej modelu, lecz nie zakłada się konkretnej postaci rozkładu składnika losowego. Założenia dotyczyć mogą jedynie pewnych cech tego rozkładu, np. wartości niektórych parametrów pozycyjnych (wartość mediany $=0$ ) lub kształtu rozkładu (rozkład symetryczny) [Manski 1975, s. 205-228; Owczarczuk 2009, s. 31-35]. W podejściu nieparametrycznym przedmiotem oceny są jedynie wartości zmiennej zależnej, budowany zaś model zależności jest wolny od parametrów i wiążących założeń. Do grupy tego typu metod należą procedury data miningowe, a wśród nich sieci neuronowe, programowanie genetyczne, uogólnione modele liniowe, a także metody klasyfikacji, np. drzewa klasyfikacyjne. Dopuszcza się również łączenie podejść w postaci modeli hybrydowych. We wszystkich tych podejściach analitycznych za funkcję zmiennych zakłócających przyjmuje się transformację kombinacji liniowej zmiennych kontrolowanych do przedziału $<0 ; 1>$ i interpretuje jako prawdopodobieństwo przynależności do grupy eksperymentalnej, czyli tzw. indeks skłonności (propensity).

Jednakże jeśli odejdzie się od założenia, że wartość budowanej funkcji ma być prawdopodobieństwem przynależności do grupy eksperymentalnej, to wówczas można również rozważać techniki analizy wielowymiarowej oparte na idei rzutowania przestrzeni wielowymiarowej, którą tworzą zmienne zakłócające, na przestrzeń o mniejszym wymiarze, w tym przestrzeń jednowymiarową. Wartości zarówno indeksu skłonności, jak i inaczej budowanej funkcji transformującej przestrzeń wielowymiarową $\mathrm{w}$ skalar stanowią bowiem podstawę porównania jednostek z grupy eksperymentalnej z jednostkami z grupy kontrolnej, tak by każdej jednostce z grupy eksperymentalnej przypisać jednostkę z grupy kontrolnej najbardziej podobnej ze względu na ich położenie w przestrzeni wielowymiarowej, transformowanej/zrzutowanej na przestrzeń jednowymiarową. W ten sposób może być również odtworzony ex post układ porównawczy, właściwy podejściu eksperymentalnemu, i możliwe jest oszacowanie efektu wpływu czynnika, który wyróżnił grupę eksperymentalną. $\mathrm{O}$ wyborze procedury transformacji wielowymiarowej przestrzeni cech zakłócają- 
cych w skalar, czy to o wartościach z przedziału $<0$; $1>$, czy z przestrzeni $\mathrm{R}$, decyduje zakres, w jakim uzyska się zbalansowanie grup w wyniku zastosowania ex post doboru wiązanego. Za podstawę oceny tego zbalansowania przyjmuje się standaryzowane obciążenie zmiennych zakłócających:

$$
S D=\frac{100\left(\bar{x}_{1}-\bar{x}_{0}\right)}{\sqrt{\frac{S_{1}^{2}+S_{0}^{2}}{2}}},
$$

gdzie: $\bar{x}_{i}-$ średnia, odpowiednio $\mathrm{w}$ grupie eksperymentalnej $(i=1)$ i kontrolnej $(i=0) ; S_{i}^{2}$ - wariancja, odpowiednio w grupie eksperymentalnej $(i=1)$ i kontrolnej $(i=0)$.

\section{Zbalansowanie grup w ocenie efektu wpływu organizacji projektu badawczego na wskaźniki realizacji badania w projekcie UDE}

W zrealizowanym badaniu dokonano porównania zakresu zbalansowania grup w wyniku zastosowania doboru wiązanego ex post według wartości zmiennej jednowymiarowej skonstruowanej na cztery sposoby. Po pierwsze, jako indeks skłonności, szacowany według podejścia parametrycznego według modelu regresji logistycznej. Po drugie, jako prawdopodobieństwo szacowane w podejściu nieparametrycznym według procedury drzewa klasyfikacyjnego, po trzecie, jako indeks skłonności szacowany według modelu hybrydowego, łączącego oba podejścia, gdzie wygenerowane węzły w modelu drzewa klasyfikacyjnego dołączono do zbioru zmiennych niezależnych modelu regresji logistycznej, i po czwarte wreszcie, dokonano transformacji przestrzeni wielowymiarowej w skalar według wielowymiarowej analizy korespondencji. Za zmienną wpływu na udział w badaniu (dostępność i gotowość współpracy przy pierwszej wizycie ankietera) przyjęto cechy realizacji procesu badawczego $\mathrm{w}$ terenie opisanego indeksem złożonym $\mathrm{z}$ takich charakterystyk, jak: dzień tygodnia pierwszej wizyty oraz pora dnia, wyróżniając trzy fazy: poranną (do godz. 12.00), popołudniową (w godz. 12.00-17.00) oraz wieczorną (po godz. 17.00). Dokonano podziału zmiennej wpływu na dwie kategorie, określając je umownie dwiema odmiennymi kategoriami uciążliwości procesu badawczego:

- pierwsza kategoria uciążliwości obejmowała próbę realizacji badania podczas pierwszej wizyty w dowolnym dniu tygodnia wieczorem (po godz. 17.00) lub w sobotę-niedzielę w godzinach popołudniowych (12.00-17.00) lub w sobotę w godzinach porannych (do 12.00),

- druga kategoria uciążliwości obejmowała próby realizacji badania w pierwszej wizycie w dniach roboczych tygodnia (pon.-pt.) w godzinach porannych lub popołudniowych (do 17.00) lub w niedzielę w godzinach porannych (do 12.00). 
Strukturę próby według tej klasyfikacji przedstawia tab. 1. Zacieniowano w niej podgrupę, którą wyróżniono jako eksperymentalną (pierwsza kategoria uciążliwości), pozostałe podkategorie utworzyły grupę kontrolną (druga kategoria uciążliwości).

Tabela 1. Struktura próby według dnia tygodnia i pory próby realizacji badania w pierwszej wizycie

\begin{tabular}{|c|c|c|c|c|c|}
\hline \multirow{2}{*}{\multicolumn{2}{|c|}{$\begin{array}{l}\text { Klasyfikacja według uciążliwości procesu } \\
\text { badawczego }\end{array}$}} & \multicolumn{3}{|c|}{ Pora pierwszego kontaktu } & \multirow{3}{*}{$\begin{array}{r}\text { Ogółem } \\
15,4 \%\end{array}$} \\
\hline & & \multirow{2}{*}{$\begin{array}{r}\text { po } 17.00 \\
3,6 \%\end{array}$} & \multirow{2}{*}{$\begin{array}{c}12.00-17.00 \\
8,6 \%\end{array}$} & \multirow{2}{*}{$\frac{\text { do } 12.00}{3,1 \%}$} & \\
\hline Dzień pierwszego kontaktu & sobota & & & & \\
\hline & niedziela & $2,5 \%$ & $4,4 \%$ & $1,4 \%$ & $8,3 \%$ \\
\hline & poniedziałek-piątek & $28,4 \%$ & $37,1 \%$ & $10,8 \%$ & $76,3 \%$ \\
\hline Ogółem & & $34,6 \%$ & $50,1 \%$ & $15,3 \%$ & $100,0 \%$ \\
\hline
\end{tabular}

Źródło: opracowanie własne na podstawie danych UDE.

W prostym porównaniu dostępności i gotowości współpracy jednostek badania w wyróżnionych dwóch kategoriach respondentów przynależnych do odmiennych kategorii uciążliwości procesu badawczego uzyskano wyższą dostępność i wyższą gotowość współpracy w grupie drugiej (odpowiednio 76,7\% i 70,1\% w pierwszej wizycie ankietera) niż w grupie pierwszej (odpowiednio $73,0 \%$ i 66,4\% w pierwszej wizycie ankietera), co sugeruje mały wpływ organizacji badania na intensywność realizacji badania w terenie. W obu przypadkach różnice nie przekraczały 4 p.p. Porównanie to jest jednak obciążone selekcyjnie. Jednostki bowiem nie były losowane $\mathrm{z}$ operatu z uwzględnieniem przynależności do dwóch porównywanych grup.

Jako zmienne zakłócające, traktowane w rozważanych modelach jako zmienne niezależne, wpływające na poziom zarówno dostępności, jak i gotowości współpracy przy pierwszej wizycie, a także na sposób realizacji badania w terenie, wyróżniono spośród cech głowy gospodarstwa domowego takie cechy demograficzne, jak: płeć, wiek, stan cywilny oraz aktywność zawodowa, a także cechy odnoszące się do kompetencji cywilizacyjnych, takie jak: posiadanie prawa jazdy oraz znajomość języka angielskiego, oraz cechy samego gospodarstwa, takie jak: kategoria miejsca zamieszkania, główne źródło dochodów, poziom dochodu ekwiwalentnego na 1 osobę w gospodarstwie oraz wielkość gospodarstwa domowego. Istotność wpływu tych zmiennych zarówno na możliwość realizacji badania w pierwszym kontakcie (dostępność i gotowość współpracy gospodarstwa domowego przy pierwszej wizycie), jak i na wybór dnia tygodnia oraz pory dnia przez realizujących badanie w terenie na podstawie wstępnego rozpoznania potwierdziły wcześniejsze analizy [Rószkiewicz $2015 ; 2016]$.

Zgodnie z ideą wyrównania porównywanych grup pod względem zmiennych zakłócających ocena wielkości efektu wpływu realizacji badania o określonej kategorii uciążliwości na dostępność i gotowość współpracy jednostek badania wymagała zbalansowania porównywanych grup jednostek ze względu wyróżnione zmienne niezależne. Zbalansowania dokonano metodą klasyfikacji według tech- 
niki najbliższych sąsiadów, dla $k=3$, według wartości zmiennej jednowymiarowej skonstruowanej na cztery wyróżnione wyżej sposoby. Rozkłady tej zmiennej w każdym z czterech rozważanych przypadków jej konstrukcji przedstawiają ryciny zestawione na rys. 1 .

a) model logitowy

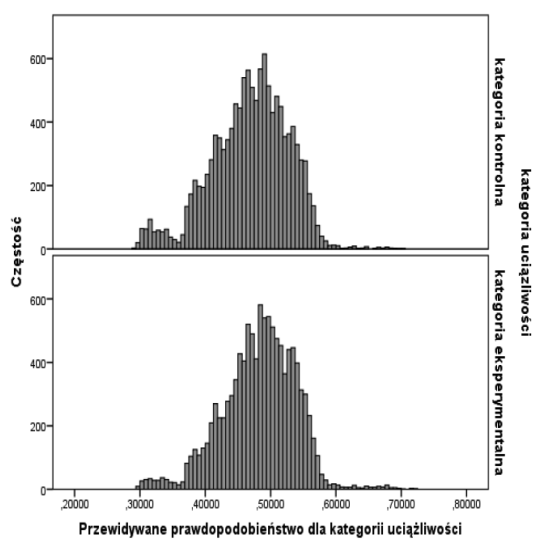

c) model hybrydowy

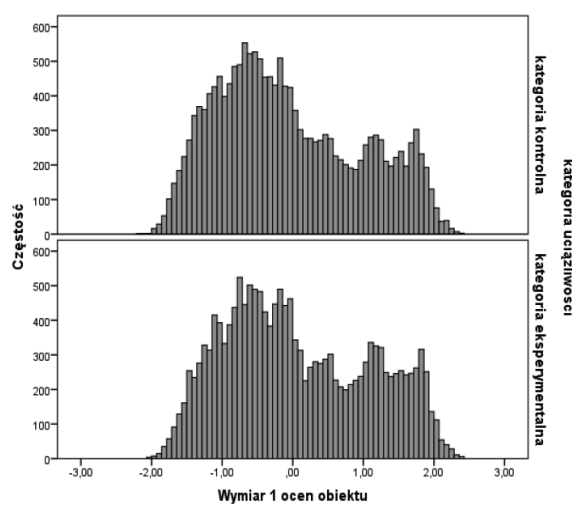

b) drzewo klasyfikacyjne

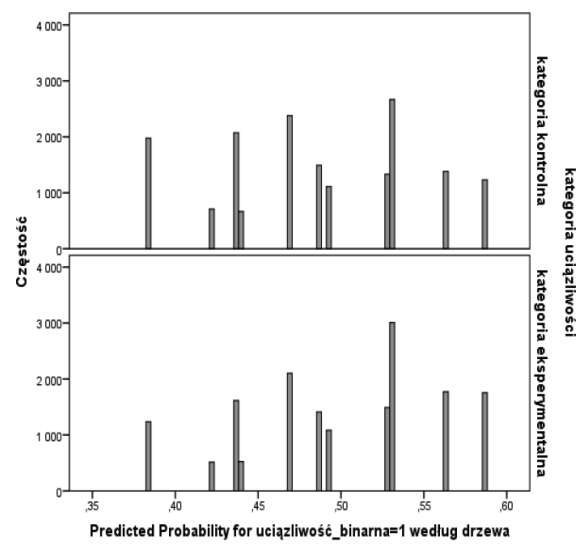

d) wielowymiarowa analiza korespondencji

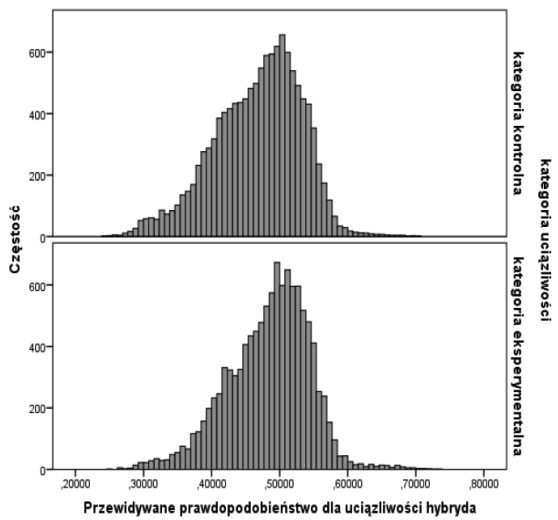

Rys. 1. Rozkłady zmiennej jednowymiarowej skonstruowanej ze zmiennych zakłócających na cztery sposoby

Źródło: opracowanie własne na podstawie danych UDE. 
Grupę eksperymentalną i grupę kontrolną do oceny wielkości efektu wpływu organizacji badania na dostępność i gotowość współpracy respondentów w pierwszej wizycie ankietera utworzyły jednostki, które miały co najmniej jednego najbliższego sąsiada z grupy przeciwnej, czyli jednostki, która miała identyczną lub najmniej różniącą się wartość skonstruowanej zmiennej służącej do porównań. To spowodowało wykluczenie niektórych jednostek, dla których nie ustalono żadnego najbliższego sąsiada z grupy przeciwnej.

\section{Wyniki zastosowanych podejść analitycznych}

W wyniku zastosowania procedury PSM (indeks skłonności szacowany według modelu regresji logistycznej) grupa eksperymentalna i kontrolna łącznie stanowiły $60,5 \%$ rozmiaru próby, co oznacza, że z porównania wyeliminowano aż 39,5\% jednostek próby, dla których nie znaleziono co najmniej jednej pary w grupie przeciwnej. W wyniku zastosowania procedury drzewa klasyfikacyjnego grupa eksperymentalna i kontrolna łącznie stanowiły $87,4 \%$ rozmiaru próby, co oznacza, że z porównania wyeliminowano jedynie $12,6 \%$ jednostek próby. W wyniku zastosowania modelu hybrydowego łączącego oba podejścia, gdzie wygenerowane węzły modelu drzewa klasyfikacyjnego dołączono do zbioru zmiennych niezależnych modelu regresji logistycznej, grupa eksperymentalna i kontrolna łącznie stanowiły $62,3 \%$ rozmiaru próby, co oznacza, że z porównania wyeliminowano $37,7 \%$ jednostek próby. $\mathrm{Z}$ kolei w wyniku wykorzystania procedury wielowymiarowej analizy korespondencji do transformacji przestrzeni wielowymiarowej w skalar grupa eksperymentalna i kontrolna łącznie stanowiły $87,0 \%$ rozmiaru próby, co oznacza, że z porównania wyeliminowano $13,0 \%$ jednostek próby. Zakres zbalansowania oceniono na podstawie standaryzowanego obciążenia zmiennych niezależnych jako standaryzowanej procentowej różnicy pomiędzy średnimi poziomami każdej kategorii zmiennej niezależnej w wyodrębnionych ex post facto ekwiwalentnych grupach, a które następnie porównano pod względem wskaźnika odpowiedzi (dostępność i gotowość współpracy). By ocenić, jak bardzo dokonana eliminacja jednostek z analizy (w wyniku braku odpowiedniej pary z grupy porównawczej) może ograniczyć walory poznawcze oszacowanego efektu zmiennej wpływu na wskaźniki realizacji badania, oceniono również zakres standaryzowanych różnic między wszystkimi jednostkami próby i grupą wyróżnioną jako eksperymentalną. W literaturze tematu uznaje się za satysfakcjonujący poziom obciążenia nie wyższy niż 3-5\%. Wartości tak zaproponowanej miary obciążenia zestawia tab. 2. Zacieniowano w niej wartości obciążenia powyżej rekomendowanego poziomu.

Warto odnotować, że wśród cech uznanych za zakłócające występowały kategorie, dla których nie udało się żadną z rozważanych metod osiągnąć zbalansowania porównywanych grup. Należą do nich: brak znajomości języka angielskiego, kategorii aktywności zawodowej jako pracujący, źródła utrzymania jako pracy na umowę, wśród klasy miejsca zamieszkania zaś zarówno gminy wiejskiej, jak i miejscowości 
Tabela 2. Standaryzowane obciążenie poszczególnych kategorii zmiennych niezależnych w porównaniu grupy wyróżnionej jako eksperymentalna z próbą ogółem oraz według wyróżnionych metod zbalansowania porównywanych grup

\begin{tabular}{|c|c|c|c|c|c|}
\hline $\begin{array}{l}\text { Kategoria zmiennej } \\
\text { niezależnej }\end{array}$ & $\begin{array}{c}\text { Wszystkie } \\
\text { jednostki próby } \\
\text { do wyróżnionej } \\
\text { grupy } \\
\text { eksperymentalnej }\end{array}$ & $\begin{array}{c}\text { Model } \\
\text { PSM } \\
(60,5 \%)\end{array}$ & $\begin{array}{c}\text { Drzewo } \\
\text { klasyfikacyjne } \\
(87,4 \%)\end{array}$ & $\begin{array}{c}\text { Model } \\
\text { hybrydowy } \\
(62,4 \%)\end{array}$ & $\begin{array}{l}\text { Model } \\
\text { MCA } \\
(87,0 \%)\end{array}$ \\
\hline 1 & 2 & 3 & 4 & 5 & 6 \\
\hline \multicolumn{6}{|c|}{ Zmienna niezależna: płeć } \\
\hline Mężczyzna & $0,4 \%$ & $0,4 \%$ & $1,5 \%$ & $0,4 \%$ & $0,3 \%$ \\
\hline Kobieta & $-0,4 \%$ & $-0,4 \%$ & $-1,5 \%$ & $-0,4 \%$ & $-0,3 \%$ \\
\hline \multicolumn{6}{|c|}{ Zmienna niezależna: grupa wieku } \\
\hline 16-18 lat & $-0,3 \%$ & $0,1 \%$ & $-0,3 \%$ & $-0,3 \%$ & $-1,1 \%$ \\
\hline 19-26 lat & $1,6 \%$ & $2,4 \%$ & $3,3 \%$ & $4,4 \%$ & $2,3 \%$ \\
\hline $27-49$ lat & $1,2 \%$ & $1,7 \%$ & $2,5 \%$ & $3,4 \%$ & $1,0 \%$ \\
\hline 50-65 lat & $-1,8 \%$ & $-2,5 \%$ & $-4,0 \%$ & $-5,1 \%$ & $-2,2 \%$ \\
\hline 66 lat i więcej & $-0,8 \%$ & $-1,5 \%$ & $-1,0 \%$ & $-2,2 \%$ & $0,2 \%$ \\
\hline \multicolumn{6}{|c|}{ Zmienna niezależna: stan cywilny } \\
\hline Kawaler \\
panna & $1,0 \%$ & $0,6 \%$ & $1,7 \%$ & $2,4 \%$ & $0,5 \%$ \\
\hline Żonaty\lzamężna & $-1,0 \%$ & $-0,4 \%$ & $-0,9 \%$ & $-1,7 \%$ & $-0,9 \%$ \\
\hline Wdowiec $\backslash$ wdowa & $-0,9 \%$ & $-1,4 \%$ & $-2,2 \%$ & $-2,4 \%$ & $-1,2 \%$ \\
\hline 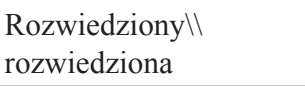 & $1,2 \%$ & $1,3 \%$ & $1,5 \%$ & $1,6 \%$ & $2,3 \%$ \\
\hline W separacji prawnej & $-0,2 \%$ & $0,2 \%$ & $-0,5 \%$ & $-0,1 \%$ & $-0,4 \%$ \\
\hline W separacji faktycznej & $-0,2 \%$ & $-0,1 \%$ & $-0,3 \%$ & $0,3 \%$ & $-0,6 \%$ \\
\hline \multicolumn{6}{|c|}{ Zmienna niezależna: prawo jazdy } \\
\hline Tak & $1,2 \%$ & $2,8 \%$ & $5,2 \%$ & $5,5 \%$ & $3,8 \%$ \\
\hline Nie & $-0,2 \%$ & $-2,8 \%$ & $-5,2 \%$ & $-5,5 \%$ & $-3,8 \%$ \\
\hline \multicolumn{6}{|c|}{ Zmienna niezależna: znajomość języka angielskiego } \\
\hline Brak znajomości & $-4,0 \%$ & $-4,0 \%$ & $-7,5 \%$ & $-9,6 \%$ & $-5,2 \%$ \\
\hline Bierna podstawowa & $1,6 \%$ & $2,3 \%$ & $2,7 \%$ & $4,4 \%$ & $2,2 \%$ \\
\hline Bierna zaawansowana & $0,7 \%$ & $0,2 \%$ & $1,2 \%$ & $0,7 \%$ & $0,5 \%$ \\
\hline Czynna podstawowa & $2,3 \%$ & $2,6 \%$ & $4,5 \%$ & $5,8 \%$ & $3,5 \%$ \\
\hline Czynna zaawansowana & $2,1 \%$ & $1,4 \%$ & $4,2 \%$ & $5,0 \%$ & $2,4 \%$ \\
\hline \multicolumn{6}{|c|}{ Zmienna niezależna: aktywność zawodowa } \\
\hline Pracujący & $3,5 \%$ & $4,6 \%$ & $7,3 \%$ & $8,4 \%$ & $4,5 \%$ \\
\hline Bezrobotni & $-1,4 \%$ & $-1,6 \%$ & $-3,3 \%$ & $-3,1 \%$ & $-2,0 \%$ \\
\hline Bierni zawodowo & $-2,9 \%$ & $-3,9 \%$ & $-5,7 \%$ & $-7,2 \%$ & $-3,6 \%$ \\
\hline
\end{tabular}


Ocena wpływu tematyki badania oraz organizacji procesu badawczego na poziom...

\begin{tabular}{|c|c|c|c|c|c|}
\hline 1 & 2 & 3 & 4 & 5 & 6 \\
\hline \multicolumn{6}{|c|}{ Zmienna niezależna: główne źródło utrzymania } \\
\hline Praca na umowę & $3,3 \%$ & $4,3 \%$ & $6,6 \%$ & $7,7 \%$ & $3,4 \%$ \\
\hline $\begin{array}{l}\text { Praca na własny } \\
\text { rachunek poza } \\
\text { gospodarstwem rolnym }\end{array}$ & $0,7 \%$ & $-0,4 \%$ & $1,4 \%$ & $1,0 \%$ & $1,9 \%$ \\
\hline $\begin{array}{l}\text { Praca na własny } \\
\text { rachunek } \\
\text { w użytkowanym } \\
\text { gospodarstwie rolnym }\end{array}$ & $-2,3 \%$ & $-2,1 \%$ & $-3,7 \%$ & $-5,4 \%$ & $-2,9 \%$ \\
\hline $\begin{array}{l}\text { Własność, dochody } \\
\text { kapitałowe }\end{array}$ & $-0,5 \%$ & $-1,1 \%$ & $-0,6 \%$ & $-2,2 \%$ & $-0,8 \%$ \\
\hline Wynajem nieruchomości & $-0,2 \%$ & $-1,0 \%$ & $-0,5 \%$ & $-0,5 \%$ & $-0,2 \%$ \\
\hline $\begin{array}{l}\text { Emerytura (krajowa } \\
\text { lub zagraniczna) }\end{array}$ & $-2,1 \%$ & $-2,2 \%$ & $-4,6 \%$ & $-4,3 \%$ & $-2,6 \%$ \\
\hline $\begin{array}{l}\text { Renta (krajowa } \\
\text { lub zagraniczna) }\end{array}$ & $-2,1 \%$ & $-2,1 \%$ & $-4,0 \%$ & $-3,9 \%$ & $-2,9 \%$ \\
\hline $\begin{array}{l}\text { Świadczenia } \\
\text { dla bezrobotnych }\end{array}$ & $-0,5 \%$ & $-1,3 \%$ & $-1,6 \%$ & $-1,5 \%$ & $-0,7 \%$ \\
\hline $\begin{array}{l}\text { Świadczenia rodzinne, } \\
\text { świadczenia z pomocy } \\
\text { społecznej, inne }\end{array}$ & $-0,5 \%$ & $-0,4 \%$ & $-1,2 \%$ & $-1,7 \%$ & $0,1 \%$ \\
\hline $\begin{array}{l}\text { Dary, alimenty i inne } \\
\text { środki uzyskane od osób } \\
\text { spoza gospodarstwa }\end{array}$ & $0,1 \%$ & $-0,1 \%$ & $0,3 \%$ & $0,0 \%$ & $0,6 \%$ \\
\hline Stypendia & $0,4 \%$ & $-0,5 \%$ & $0,8 \%$ & $0,8 \%$ & $1,3 \%$ \\
\hline Inne źródła przychodów & $0,4 \%$ & $0,4 \%$ & $0,9 \%$ & $0,2 \%$ & $0,2 \%$ \\
\hline \multicolumn{6}{|c|}{ Zmienna niezależna: grupa dochodu ekwiwalentnego na 1 osobę } \\
\hline do $800 \mathrm{zl}$ & $-4,9 \%$ & $-2,3 \%$ & $-4,7 \%$ & $-5,3 \%$ & $-3,0 \%$ \\
\hline $800,01 \mathrm{zł}-1500 \mathrm{zł}$ & $-2,8 \%$ & $-1,8 \%$ & $-2,4 \%$ & $-3,4 \%$ & $-1,7 \%$ \\
\hline $1500,01 \mathrm{zl}-2200 \mathrm{zł}$ & $1,9 \%$ & $1,5 \%$ & $2,2 \%$ & $2,2 \%$ & $1,2 \%$ \\
\hline 2200,01 zł-2900 zł & $3,5 \%$ & $1,9 \%$ & $3,1 \%$ & $4,4 \%$ & $1,5 \%$ \\
\hline $2900,01 \mathrm{zl}-3600 \mathrm{zl}$ & $4,8 \%$ & $2,4 \%$ & $4,5 \%$ & $5,0 \%$ & $3,9 \%$ \\
\hline powyżej 3600 zł & $1,5 \%$ & $0,2 \%$ & $1,7 \%$ & $1,3 \%$ & $0,6 \%$ \\
\hline \multicolumn{6}{|c|}{ Zmienna niezależna: klasa miejsca zamieszkania } \\
\hline Gmina wiejska & $-5,2 \%$ & $-5,7 \%$ & $-7,0 \%$ & $-10,7 \%$ & $-8,1 \%$ \\
\hline $\begin{array}{l}\text { Miasto do } 10 \text { tys. } \\
\text { mieszkańców }\end{array}$ & $0,1 \%$ & $-0,6 \%$ & $-0,7 \%$ & $-1,0 \%$ & $0,5 \%$ \\
\hline $\begin{array}{l}\text { Miasto } 10 \text { 000-19 } 999 \\
\text { mieszkańców }\end{array}$ & $-0,6 \%$ & $-0,2 \%$ & $-2,0 \%$ & $-3,1 \%$ & $-1,6 \%$ \\
\hline $\begin{array}{l}\text { Miasto } 20 \text { 000-49 } 999 \\
\text { mieszkańców }\end{array}$ & $-1,3 \%$ & $-0,1 \%$ & $-4,5 \%$ & $-1,6 \%$ & $-1,9 \%$ \\
\hline
\end{tabular}


Tabela 2, cd.

\begin{tabular}{|c|c|c|c|c|c|}
\hline $\begin{array}{l}\text { Miasto } 50 \text { 000-99 } 999 \\
\text { mieszkańców }\end{array}$ & $-0,7 \%$ & $0,9 \%$ & $-3,9 \%$ & $0,9 \%$ & $-1,4 \%$ \\
\hline $\begin{array}{l}\text { Miasto } 100 \text { 000-199 } 999 \\
\text { mieszkańców }\end{array}$ & $1,5 \%$ & $0,2 \%$ & $2,2 \%$ & $1,4 \%$ & $3,0 \%$ \\
\hline $\begin{array}{l}\text { Miasto } 200 \text { 000-499999 } \\
\text { mieszkańców }\end{array}$ & $3,1 \%$ & $3,4 \%$ & $6,0 \%$ & $6,2 \%$ & $4,7 \%$ \\
\hline $\begin{array}{l}\text { Miasto } 500 \text { 000-999 } 999 \\
\text { mieszkańców }\end{array}$ & $3,3 \%$ & $2,8 \%$ & $6,6 \%$ & $6,4 \%$ & $5,4 \%$ \\
\hline Warszawa & $4,1 \%$ & $4,1 \%$ & $8,8 \%$ & $9,4 \%$ & $-8,1 \%$ \\
\hline \multicolumn{6}{|c|}{ Zmienna niezależna: liczba osób w gospodarstwie domowym } \\
\hline 1 & $1,3 \%$ & $0,4 \%$ & $2,4 \%$ & $3,0 \%$ & $1,4 \%$ \\
\hline 2 & $0,1 \%$ & $0,3 \%$ & $-0,8 \%$ & $-1,0 \%$ & $-0,2 \%$ \\
\hline 3 & $0,1 \%$ & $0,1 \%$ & $0,1 \%$ & $0,0 \%$ & $0,2 \%$ \\
\hline 4 & $0,0 \%$ & $0,8 \%$ & $0,5 \%$ & $1,1 \%$ & $0,9 \%$ \\
\hline 5 & $-1,0 \%$ & $-0,6 \%$ & $-1,0 \%$ & $-1,3 \%$ & $-2,1 \%$ \\
\hline 6 & $-1,3 \%$ & $-1,5 \%$ & $-2,3 \%$ & $-3,2 \%$ & $-0,9 \%$ \\
\hline 7 & $-2,2 \%$ & $-3,0 \%$ & $-3,6 \%$ & $-5,2 \%$ & $-3,0 \%$ \\
\hline 8 & $-0,4 \%$ & $-0,5 \%$ & $-0,6 \%$ & $-2,1 \%$ & $0,0 \%$ \\
\hline 9 & $-0,7 \%$ & $-0,7 \%$ & $-1,0 \%$ & $0,1 \%$ & $-0,8 \%$ \\
\hline 10 & $-1,2 \%$ & $-1,8 \%$ & $-2,2 \%$ & $-1,4 \%$ & $-1,5 \%$ \\
\hline $\begin{array}{l}\text { Efekt wpływu } \\
\text { na dostępność }\end{array}$ & 3,7 p.p. & 28,4 p.p. & 18,0 p.p. & 26,5 p.p. & 20,0 p.p. \\
\hline $\begin{array}{l}\text { Efekt wpływu } \\
\text { na współpracę }\end{array}$ & 3,8 p.p. & 25,6 p.p. & 16,5 p.p. & 23,9 p.p. & 18,3 p.p. \\
\hline
\end{tabular}

Źródło: opracowanie własne na podstawie danych UDE.

o liczbie mieszkańców od 500 tys. oraz Warszawy. Brak zbalansowania porównywanych grup ze względu na te cechy obciąża uzyskane oceny wielkości wpływu każdą z rozważanych metod. Jednak biorąc pod uwagę wszystkie oceny standaryzowanych różnic, należy uznać, że zdecydowanie najlepsze zbalansowanie osiągnięto w przypadku zastosowania metody PSM, niewiele gorsze zaś i w zasadzie można powiedzieć, że porównywalne, osiągnięto w przypadku zastosowania wielowymiarowej analizy korespondencji (MCA). Zaletą tego drugiego rozwiązania jest również to, iż $\mathrm{w}$ tym drugim przypadku do analizy porównawczej dopuszczono znacznie więcej jednostek próby, co zwiększa zakres wykorzystywania dostępnej informacji i tym samym walor poznawczy szacowanego efektu zmiennej wpływu. Za najgorsze rozwiązanie należy uznać wynik według procedury modelu hybrydowego, w którego przypadku zakres zbalansowania porównywanych grup w niewielkim stopniu przekroczył tylko połowę kategorii rozważanych zmiennych niezależnych, z analiz 
porównawczych zaś wyeliminowano praktycznie co trzecią jednostkę próby. Warunki realizacji analizy porównawczej według modelu PSM oraz MCA wydają się bardzo dobre. Dysponowano próbą o znacznej liczebności, a jednostki wyróżnione czynnikiem kontrolowanym (przynależne do grupy eksperymentalnej) w niewielkim stopniu różniły się od wszystkich jednostek próby pod względem rozkładu wyróżnionych zmiennych niezależnych. Wyniki wskazują, że wielkości efektu wpływu organizacji badania w terenie, jeśli wziąć pod uwagę kategorię oznaczoną jako druga względem kategorii uznanej jako pierwsza, według metody PSM wynoszą średnio 25,6 p.p., według MCA zaś 18,3 p.p.

Potencjalne skutki rozważanych koncepcji organizacji badania w terenie powinny być szacowane na podstawie pilotażu wraz z informacjami o zróżnicowaniu cech stanowiących podstawę określania rozmiarów próby oraz kosztów jednostkowych projektu. Pozwoliłoby to znacznie uprościć i skrócić proces pomiaru terenowego, a także zredukować koszty prób rezerwowych i wielokrotnych wizyt ankieterów.

\section{Literatura}

Aakar D.A., Day G.S., Marketing Research, John Wiley \& Sons Inc., Toronto 1990.

Gruszczyński M., 2002, Modele i prognozy zmiennych jakościowych w finansach i bankowości, Oficyna Wydawnicza SGH, Warszawa.

Goyder J., 1987, Surveys on surveys: limitation and potentialities, Public Opinion Quarterly, vol. 50, s. $27-41$.

Groves R.M., Couper M.P., 1998, Noresponse in Household Interview Surveys, Wiley, New York.

Lynn P., 2002, PEDAKSOIS: Methodology for Collecting Data about Survey Non-respondents, Working Papers of the Institute for Social and Economic Research, paper 2002-05, University of Essex Colchester. www.iser.essex.ac.uk/pubs/workpaps/isr/2002-05.pdf.

Maddala G.S., 2001, Introduction to Econometrics, third edition, John Wiley \& Sons, Ltd., Chichester.

Manski C.F., 1975, Maximum score estimation of the stochastic utility model of choice, Journal of Econometrics, 3, s. 205-228.

Owczarczuk M., 2009, Maximum score type estimators, Central European Journal of Economic Modeling and Econometrics, nr 1, Rosenbaum, Rubin.

Rosenbaum P.R., Rubin D.B., 1983, The Central role of the Propensity Score in Observational Studies for Causal Effect, Biometrika, vol. 70, no.1, s. 41-55.

Rószkiewicz M., 2015, Próba diagnozy uwarunkowań poziomu wskaźnika braku odpowiedzi w środowisku polskich gospodarstw domowych, Prace Naukowe Uniwersytetu Ekonomicznego we Wrocławiu nr 385, UE, Wrocław, s. 219-228.

Rószkiewicz M., 2016, Czynniki różnicujące efektywność pracy ankietera w wywiadach face-to-face w środowisku polskich gospodarstw domowych, Prace Naukowe Uniwersytetu Ekonomicznego we Wrocławiu nr 426, UE, Wrocław, s. 166-173.

Stinchcombe A.L., Jones C., Sheatsley P., 1981, Nonresponse bias for attitude questions, Public Opinion Quarterly, vol. 45, s. 359-375. 